Козак Людмила

доктор педагогічних наук, доцент, професор кафедри дошкільної освіти

Київського університету імені Бориса Грінченка, м. Київ, Україна

ORCID: 0000-0002-4528-1905

e-mail:l.kozak@kubg.edu.ua

\title{
ТЕХНОЛОГІЇ РОЗВИТКУ ТВОРЧОГО МИСЛЕННЯ МАЙБУТНІХ ПЕДАГОГІВ ДОШКІЛЬНОЇ ОСВІТИ
}

\begin{abstract}
Анотація. У статті проаналізовано дослідження вітчизняних та зарубіжних науковців, які розглядають технології, спрямовані на розвиток творчого мислення студентів; проаналізовано поняття «творчість», механізми творчого мислення, його специфічні ознаки, етапи творчого процесу; охарактеризовано технологію проблемного навчання, яка найповніше відповідає завданням розвитку творчого мислення студентів та подано змістову характеристику теорії розв'язання винахідницьких завдань (ТРВ3) як технології розвитку творчої особистості; розкрито сутність, основні ознаки, алгоритм технологій; визначено переваги та труднощі у використанні зазначених технологій. Зроблено висновок щодо можливості застосування технологій проблемного навчання та методів $\mathrm{i}$ прийомів ТРВЗ у роботі з майбутніми педагогами дошкільного профілю в освітньому процесі закладу вищої освіти.
\end{abstract}

Ключові слова: алгоритм; метод; прийом; проблемне навчання; творчість; творче мислення; теорія розв'язання винахідницьких завдань; технологія.

Постановка проблеми. Активізація творчої та інноваційної діяльності в освіті, розвиток творчого потенціалу майбутнього педагога, підготовка його до активної участі в інноваційних перетвореннях у сфері професійної діяльності набуває особливого значення в інформаційному суспільстві. Пріоритетними критеріями сучасного педагога дошкільної освіти $\epsilon$ високий інтелектуальний та професійний рівень, вміння вирішувати складні завдання, генерувати нові ідеї (креативність) та творче мислення.

Необхідність розробки питання формування та розвитку творчої особистості, реалізації іiі задатків та потенційних можливостей підтверджується низкою державних нормативно-правових документів, зокрема, Законами України «Про освіту», «Про вищу освіту», «Про наукову та науково-технічну діяльність», Концепцією розвитку педагогічної освіти, що відображає ключові тенденції реформи, 


\section{Інноватика у вихованні. Випуск 14. 2021.}

Концепцією «Нова українська школа», Стандартами вищої освіти тощо. У зв'язку з цим, особливої актуальності набуває проблема розвитку творчого мислення майбутнього педагога дошкільної освіти як основи його професійного становлення та особистісного зростання.

Аналіз останніх досліджень і публікацій. Проблема творчості та творчого мислення досліджена у наукових працях М. М. Бахтіна, Л. С. Виготського, Н. Д. Дружиніна, М. С. Когана, О. М. Леонтьєва, Я. О. Пономарьова, С. Л. Рубінштейна, Л. В. Сохань, В. І. Шинкарука та ін. Психолого-педагогічні аспекти розвитку творчої особистості вивчали Г. С. Альтшуллер, Г. С. Костюк, О. М. Матюшкін, В. О. Моляко, В. В. Рибалко, М. О. Холодна та ін. Основні положення педагогічної творчості висвітлено в працях В. І. Загв'язинського, В. О. Кан-Калика, О. В. Киричука, Н. В. Кічук, О. М. Поташника, С. О. Сисоєвої та ін. Формування творчого мислення майбутнього вчителя в умовах університетської освіти проаналізовано О. В. Акімовою. Технології проблемного навчання розроблено в працях Я. Лернера, О. М. Матюшкіна, М. М. Махмутова, М. М. Скаткіна та ін. Сучасні технології стимулювання творчої активності студентів представлено в працях І. М. Дичківської, О. І. Пометун, Л. С. Подимової, С. О. Сисоєвої та ін. Освітній потенціал ТРВ3 досліджено С. А. Болсун, О. В. Лесіна, В. П. Телячук та ін. Аналіз наукових праць засвідчує, що розвиток творчого мислення майбутніх педагогів має бути одним із пріоритетних завдань вищої освіти.

Мета статті - проаналізувати змістові характеристики технологій проблемного навчання, ТРВ3 та визначити їх вплив на розвиток творчого мислення майбутніх педагогів дошкільного профілю.

Виклад основного матеріалу дослідження. У сучасній науковій літературі існують різні підходи до визначення сутності творчості. Творчість розглядають як механізм розвитку, руху, зміни (А. Я. Пономарьов та ін.); діяльність зі створення нового, оригінального, що входить не тільки в історію розвитку самого творця, але й в історію розвитку науки, мистецтва (С. Р. Рубінштейн); «алгоритм дій, діяльність певною мірою структуровану», до якої входять такі елементи, як усвідомлення проблеми, іii розв'язання, а також перевірка рішення (Г. С. Альтшуллер); процес створення, відкриття нового, що раніше для визначеного конкретного суб'єкту було невідомим (В. О. Моляко).

Таким чином, творчість в освітньому контексті доцільно розглядати як конструктивну діяльність зі створення як об'єктивно, так і суб'єктивно нового, як процес розвитку сутнісних сил особистості.

Виділяючи ознаки творчого акту, практично всі дослідники творчості і самі творці підкреслювали іiі несвідомість, спонтанність, некерованість волею і розумом (Акімова, 2007, с. 125).

Нове розуміння механізму творчого мислення представлене у дослідженнях Я. О. Пономарьова. Він розробляє структурно-рівневу концепцію психологічного механізму творчого мислення. Дослідник розуміє мислення як єдність інтуїтивного і логічного. Психологічний 


\section{Інноватика у вихованні. Випуск 14. 2021.}

механізм творчого мислення, коли проблема вже поставлена, може бути розподілено на чотири фази: 1) логічний аналіз, виникнення потреби в новому, поява пошукової домінанти; 2) інтуїтивне рішення, неусвідомлене (інсайт); 3) вербалізація інтуїтивного рішення - поглиблення усвідомленості рішення задачі; 4) формалізація вербального рішення надання йому логічно завершеної форми. Найважливіша особливість цього механізму - єдність логічного та інтуїтивного, усвідомленого і неусвідомленого, прямого і побічного (там само, с.136-137).

На основі вище зазначеного, можемо зробити висновок, що творчість педагога - процес керований. Він проходить у чотири етапи: 1) підготовка (свідома робота на рівні понятійно-логічного мислення); 2) дозрівання (несвідома робота над проблемою); 3) осяяння (перехід несвідомого у свідоме, інакше кажучи, народження гіпотези); 4) розвиток ідей (свідома робота по остаточному оформленню ідеї та її перевірки).

На думку психологів, основу творчого мислення утворюють такі риси: самостійне перенесення знань і вмінь у нову ситуацію; бачення нових проблем у знайомих, стандартних умовах; бачення нової функції знайомого об'єкту; бачення структури об'єкту, що підлягає вивченню; уміння комбінувати раніше відомі способи розв'язання проблем в новий спосіб і вміння створювати оригінальний спосіб розв'язання тощо (Сисоєва, 2014, с. 56).

Важлива умова розвитку творчого мислення педагогів - творча організація їх професійної підготовки, що передбачає активно творчий тип засвоєння знань; оптимізацію процесу сприйняття, осмислення і творчого застосування набутих педагогічних умінь i навичок; використання технологій і методів, які спрямовані на розвиток творчих здібностей майбутніх педагогів.

Технологія проблемного навчання найповніше відповідає завданням розвитку творчого мислення студентів. У зарубіжній педагогіці концепцію проблемного навчання розвивав американський педагог Дж. Дьюї (18591952), який стверджував, що мислення - це вирішення проблем. Він вважав, що навчальний процес повинен будуватися за схемою мислення: виникнення проблемної ситуації - аналіз даних - висунення гіпотези - iї перевірка. Найповніше проблемне навчання розроблене у працях I. Я. Лернера, О. М. Матюшкіна, М. М. Махмутова, М. М. Скаткіна та ін.

Під проблемним навчанням розуміють таку організацію навчальних занять, котрі передбачають створення під керівництвом викладача проблемних ситуацій і активну самостійну діяльність студентів щодо їх розв'язання, результатом якої є творче оволодіння знаннями, навичками, уміннями та розвиток мислительних здібностей (Вітвицька, 2003).

Для створення проблемної ситуації використовують наступні прийоми: пряма постановка проблеми; проблемне завдання у вигляді запитання; повідомлення інформації, яка містить суперечність; повідомлення протилежних думок з будь-якого питання; звернення уваги на те чи інше життєве явище, яке потрібно пояснити; повідомлення фактів, 


\section{Інноватика у вихованні. Випуск 14. 2021.}

які викликають непорозуміння; співставлення життєвих уявлень 3 науковими; постановка питання, на яке повинен відповісти студент, прослухавши частину лекції, і зробити висновки.

Загалом можна назвати такі етапи вирішення проблеми:1) виникнення проблемної ситуації; 2) вирізнення проблем, їх аналіз; 3) висунення гіпотез, пошук нових засобів вирішення; 4) аналіз гіпотез, знаходження способів вирішення проблеми; 5) перевірка правильності вирішення проблеми; 6) самостійне оперування набутими знаннями, вміння використовувати їх у нових і нестандартних ситуаціях.

Вирішення проблемної ситуації вимагає включення творчого мислення. Велике значення має також мотиваційна сторона проблемної ситуації, наявність у студента такого рівня знань, умінь і навичок, який був би достатнім, щоб почати пошук невідомого результату або способу виконання завдання.

Найважливіша риса змістовного аспекту проблемного навчання - це відображення об'єктивних протиріч, які закономірно виникають у процесі наукового пізнання, навчальної або будь-якої іншої діяльності, які і $\epsilon$ джерелом руху і розвитку в будь-якій галузі. Під час проблемного навчання процес мислення включається лише 3 метою вирішення проблемної ситуації, таке навчання формує мислення, необхідне для вирішення нестандартних завдань.

Основними рівнями проблемного навчання і одночасно шляхами його реалізації $\epsilon: 1)$ проблемний виклад навчального матеріалу в монологічному режимі лекції чи діалогічному режимі семінару, коли викладач пропонує проблему, висуває проблемні завдання і сам показує шляхи їх вирішення, при цьому студенти виносять свої припущення, формують ставлення до навчального матеріалу; 2) частково-пошукова діяльність при виконанні експерименту, на лабораторних заняттях; проблему ставить викладач, а студенти під його керівництвом її вирішують; 3) самостійна дослідницька діяльність, коли студенти самі усвідомлюють проблему, формулюють і вирішують iі, самостійно проходять всі етапи дослідження: спостереження, досліди, висування i перевірка гіпотез, робота 3 теоретичними джерелами, моделювання, статистичні методи, висновки.

Таким чином, проблемне навчання активізує i розвиває творче мислення студентів та інші пізнавальні процеси; формує самостійність, відповідальність, критичність і самокритичність, ініціативність; забезпечує міцність набутих знань, сприяє перетворенню знань у переконання.

Разом 3 тим, існують обмеження в застосуванні технології проблемного навчання, обумовлені наступними обставинами: застосування технології проблемного навчання вимагає від викладача певних знань, педагогічної майстерності, творчості; таке навчання передбачає своїм змістом матеріал високого рівня значущості, що допускає неоднозначні, альтернативні підходи, тлумачення й оцінки; проблемне 


\section{Інноватика у вихованні. Випуск 14. 2021.}

навчання можливе тоді, коли у студентів $є$ необхідний рівень знань, певний досвід в галузі, що вивчається.

Зазначимо, що технологія проблемного навчання реалізується на практиці як самостійна, автономна або як органічна частина інших технологій навчання (ігрових технологій, технологій кооперативного, проєктного навчання та ін.).

Досягнення творчого рівня розвитку особистості можна вважати найвищим результатом будь-якої педагогічної технології, але існують технології, в яких розвиток творчих здібностей є пріоритетною метою. Серед них чільне місце посідає ТРВ3 - теорія розв'язання винахідницьких завдань, яка ефективно сприяє розвиткові технічної творчості загалом i творчої особистості зокрема. Створена вона вченим-дослідником, письменником-фантастом Генріхом Альтшуллером. На відміну від методик, які становлять сукупність окремих прийомів, ТРВ3 є цілісною, самодостатньою технологією, послуговуючись якою можна розв'язувати проблеми будь-якої складності (Дичківська, 2012, с. 222-223).

Поширеною є думка, що винаходи приходять несподівано, з осяянням чіткого розуміння чого небудь, але Г. Альтшуллер задався метою виявити, як створюються винаходи, і чи є у творчості свої закономірності. Для цього він дослідив понад 40 тисяч патентів і авторських свідоцтв, класифікував рішення по 5-ти рівнях винахідливості і виділив 40 стандартних прийомів, використаних винахідниками. В результаті ним був розроблений алгоритм розв'язання винахідницьких завдань (АРВ3) - покрокова програма 3 виявлення і вирішення протиріч. Це і стало ядром ТРВЗ. Головне місце в технології належить життєвій стратегії творчої особистості (ЖСТО) та розвитку творчої уяви (РТУ) (Подимова, та ін., 2011).

Поява ТРВ3 була викликана потребою прискорити винахідницький процес, виключивши 3 нього елементи випадковості: раптове i непередбачуване осяяння, сліпий перебір і відкидання варіантів, залежність від настрою тощо. Крім того, метою ТРВЗ було поліпшення якості і збільшення рівня винаходів за рахунок зняття психологічної інерції та посилення творчої уяви і мислення. Поступово ця теорія вийшла за межі технічної галузі і почала використовуватися в гуманітарних та інших галузях, у тому числі й в педагогіці.

Основні положення ТРВЗ стосовно педагогіки, сформульовані Г. К. Селевко: 1) теоретичні знання - каталізатор творчого розв'язання проблеми, інструмент та основа творчої інтуїції; 2) винаходити можуть всі, оскільки творчими здібностями наділена кожна людина; 3) творчості, як і будь-якої діяльності можна навчитися; 4) необхідно включати в зміст освіти основні доступні учням типи проблем, що $є$ характерними для певної науки i практики; 5) в центрі ТРВЗ знаходиться поняття суперечності.

Мета використання ТРВ3 у підготовці майбутніх педагогів формування і розвиток культури творчого мислення, здатності вирішувати складні завдання витонченими й ефективними способами. 


\section{Інноватика у вихованні. Випуск 14. 2021.}

ТРВ3 - це набір методів вирішення завдань і удосконалення систем, в основі яких лежить креативний підхід. ТРВ3 можна вважати єдиною системною теорією навчання творчості, тому вирішення завдань не можна оцінити, до того ж єдиної правильної відповіді вирішення немає.

Головний принцип ТРВЗ базується на твердженні, що кожне завдання має нескінченну кількість розв'язань. Умови завдань мають бути загальними, абстрактними, не пов'язаними 3 конкретними життєвими ситуаціями. Ще одна важлива умова формулювання творчого завдання ТРВ3 - орієнтація на результат (Баландіна, 2020).

ТРВ3 передбачає наявність винахідницьких задач і саме тоді, коли вони виникають, починається потреба в застосуванні технології їх розв'язання.

Розв'язання будь-якої винахідницької задачі передбачає отримання певного результату, також звісно припускається ідеальний кінцевий результат, тобто ситуація, коли потрібна дія виходить без будь-яких витрат (втрат), використання зовнішніх ресурсів, ускладнень і небажаних ефектів лише доступними ресурсами (Освітній потенціал ТРВ3, 2014).

Наприклад, лекційне заняття має бути інформаційним та змістовним, щоб студенти повністю засвоїли певну тему, з іншого боку, воно має також бути цікавим та практико-орієнтованим. Це простий приклад протиріччя лекція одночасно повинна бути навантаженою інформацією і цікавою для сприйняття. Вирішенням цього завдання є застосування різноманітних інноваційних методів і технологій, наприклад, модель змішаного навчання «перевернутий клас».

Алгоритм розв'язання винахідницьких завдань (АРВ3) включає в себе програму; інформаційне забезпечення; методи управління психологічними чинниками, що перешкоджають розвитку творчої уяви (Подымова, 2011).

В освітній практиці для розв'язання винахідницьких завдань зазвичай використовують шість основних етапів: 1) формування міні-задачі, яка сприятиме більш точному опису завдання; 2) формування проблеми у вигляді протиріч; 3) моделювання ідеального кінцевого результату; 4) визначення необхідних ресурсів для вирішення завдання; 5) застосування одного $з$ прийомів або методів для вирішення завдання; 6) аналіз результату та безпосередній розвиток критичного мислення (виділення позитивного і негативного в результаті).

Під методами розв'язання винахідницьких задач, перш за все, маються на увазі прийоми і алгоритми, розроблені в рамках ТРВ3; а також такі відомі методи як мозковий штурм, синектика, морфологічний аналіз, метод фокальних об'єктів та їх різновиди. Розглянемо деякі з них:

Прийом «Збільшення - зменшення». Суть прийому «збільшення зменшення» полягає в зміні по спадній чи зростаючій будь-якої ознаки об'єкта в сторону збільшення чи зменшення

Прийом «Ділення - об'єднання». Цей прийом призначений для перетворення 3 позиції ділення й комбінування у будь-якому варіанті об’єктів чи їхніх частин. Основний принцип дії Ділення, яке усе ділить, і 


\section{Інноватика у вихованні. Випуск 14. 2021.}

Об’єднання, яке усе поєднує, відсутність будь-яких правил, нелогічність ділення і комбінування.

Прийом «Перетворення ознак часу». Фантазування, засноване на зміні ознак часу. У зв'язку з тим, що для перетворення беруться різні властивості часу, прийом стає багатофункціональним. Час може бути різних типів: Швидкі Хвилини (прискорює процеси, які протікають у самому об'єкті); Повільні Хвилини (уповільнює процеси); Зворотній Час (змушує протікати події у зворотній послідовності); Машина Часу (переміщує об'єкти на далекі часові відрізки); Дзеркало Часу (переміщує об’єкти на ближчі часові відрізки); Зупинка Часу (зупиняе час для об'єкта, його частин чи місця знаходження).

Прийом «Спеціалізація - універсалізація». Прийом представлено двома поняттями: універсалізації і спеціалізації. Прийом Універсалізації дає можливість об'єкту виконувати безліч функцій, навіть йому не властивих. Прийом Спеціалізації дозволяє обмежити можливості об'єкта в рамках типової для нього функції.

Прийом «Навпаки». Суть прийому полягає у виявленні певної ознаки або значення ознаки об'єкта та заміні ії на протилежні.

ТРВ3 грунтується на наступних методах пошуку рішень (Сходинками творчості. Методика ТРВЗ в початковій школі, 2007).

Мозковий штурм - колективний пошук нетрадиційних шляхів розв'язання проблеми. Під час проведення мозкового штурму пошуковий процес має два етапи: І етап. Група «генераторів ідей» у бесіді висуває різні пропозиції. II етап. Критики оцінюють результати штурму й вибирають кращі пропозиції.

Синектика - найкращий метод 3 різновидів «мозкового штурму». Особливостями iï $\epsilon$ дозвіл на критику. А головне - обов'язкове застосування грунтованих на аналогії 4-х прийомів: 1) прямої аналогії: як раніше розв'язувалися подібні проблеми; 2) особистісної або емпатичної спробувати ввійти в образ даного об'єкта й розв'язати проблему з його точки зору; 3) символічної (дати коротке символічне визначення проблеми); 4) фантастичної - уявити, як би це розв'язували фантастичні персонажі.

Морфологічний аналіз - метод що дозволяє формувати рухливість мислення, розвиває комбінаторику. Розумові операції комбінаторного характеру здійснюються за допомогою таблиці, де по вертикалі та горизонталі виставляються будь-які показники. Перетин значень цих показників є основою аналітичної діяльності.

Метод фокальних об'єктів. Основна ідея - встановлення асоціативних зв'язків визначеного об'єкта з випадковими об'єктами або їх ознаками.

Отже, ТРВ3 є універсальною технологією, що стимулює творче мислення, розвиває фантазію, яка знаходить втілення в практичній діяльності; мотивує до обміну оригінальними ідеями; формує здатність пропонувати нестандартні рішення, шукати вихід із скрутної ситуації, 


\section{Інноватика у вихованні. Випуск 14. 2021.}

поглянути на проблему під іншим кутом зору; допомагає відчути смак успіху в досягненні поставлених цілей.

Водночас існують певні труднощі у застосуванні ТРВ3, обумовлені такими обставинами: потрібен тривалий час для навчання, як і будь-якого іншого навчального предмету. Ефективність застосування ТРВЗ залежить від ступеня іiі вивчення (наприклад, скільки творчих прийомів може застосовувати людина в своїй діяльності - 5 або 50). Немає однозначності і точності інструментів. При вирішенні завдань доводиться перебирати всі інструменти.

Висновки і перспективи подальших розвідок. Аналіз наукових джерел із проблеми дослідження свідчить про можливості технології проблемного навчання і ТРВЗ для розвитку творчого мислення майбутніх педагогів. Проблемне навчання сприяє формуванню у студентів особливого стилю розумової діяльності, дослідницької активності, самостійності; дозволяє майбутнім педагогам актуалізувати творчий потенціал та розвинути творче мислення. Прийоми, методи та алгоритми ТРВ3 можуть бути успішно використані в індивідуальній і колективній дослідницькій роботі студентів. Під час дослідницької роботи, студенти зможуть спрямувати свої ресурси на спільний пошук вирішення проблемної задачі; вивчення конкретних ситуацій; обговорення отриманих результатів; виконання випереджаючих знань для наступних занять тощо. Теорія розв'язання винахідницьких завдань дає можливість дослідницького пошуку нестандартних рішень, вибору найбільш оптимального підходу до вирішення різних типів завдань, прийняття творчих рішень при розв'язанні проблемних ситуацій, сприяє засвоєнню знань і формуванню професійних компетентностей на більш високому рівні.

Підготовка майбутніх педагогів дошкільної освіти потребує подальшого вивчення i упровадження сучасних технологій розвитку творчого мислення в освітній процес, що і стане подальшим напрямом наших наукових розвідок.

\section{СПИСОК ВИКОРИСТАНИХ ДЖЕРЕЛ}

Акімова, О. (2007). Теоретико-методичні засади формування творчого мислення майбутнього вчителя в умовах університетської освіти : Монографія. Вінниця, $351 \mathrm{c}$.

Баландина, А. ТРИЗ как метод творческого мышиления. URL: https://netology.ru/blog/06-2020-what-is-triz [Дата звернення 10.09.2021].

Вітвицька, С. (2003). Основи педагогіки вищої иколи : Методичний посібник для студентів магістратури. Київ : Центр навчальної літератури, 316 с.

Дичківська, І. (2012). Інновачійні педагогічні технологї̈ : підручник / 2-ге вид., доповн. Київ: Академвидав, 352 с.

Освітній потенціал ТРВ3 (теорія розв'язання винахідницьких задач). (2014). Частина 1 / С. А. Болсун. Харків: Вид. група «Основа», 128 с.; Вип. 5 (137).

Подымова, Л., Сергеева, В., Сороковых, Г. (2011). Интерактивные методы 8 обучении и воспитании в системе общего, среднего и высшего профессионального 


\title{
Інноватика у вихованні. Випуск 14. 2021.
}

образования. Учебно-методическое пособие, Москва. URL: https://lektsii.org/836203.html

Сисоєва, С. (2014). Творчий розвиток фахівців в умовах магістратури: Монографія. Київ: ТОВ. «Виробниче підприємство «ЕДЕЛЬВЕЙС», 400 с.

Сходинками творчості. Методика ТРВЗ в початковій иколі (2007). Авториупорядники: О. В. Лесіна, В. П. Телячук. Х.: Вид. група «Основа»: «Тріада+», 112c.

\section{REFERENCES}

Akimova, O. (2007). Teoretyko-metodychni zasady formuvannia tvorchoho myslennia maibutnoho vchytelia $v$ umovakh universytetskoi osvity '[Theoretical and methodical bases of formation of creative thinking of the future teacher in the conditions of university education]: Monohrafiia. Vinnytsia, 351 s. [in Ukrainian].

Balandina, A. TRIZ kak metod tvorcheskogo myshleniya. [TRIZ as a method of creative thinking]. URL: https://netology.ru/blog/06-2020-what-is-triz [Data zvernennya 10.09.2021]. [in Ukrainian].

Vitvytska, S. (2003). Osnovy pedahohiky vyshchoi shkoly [Fundamentals of higher school pedagogy]: Metodychnyi posibnyk dlia studentiv mahistratury. Kyiv: Tsentr navchalnoi literatury, $316 \mathrm{~s}$. [in Ukrainian].

Dychkivska, I. (2012). Innovatsiini pedahohichni tekhnolohii [Innovative pedagogical technologies]: pidruchnyk / 2-he vyd., dopovn. Kyiv: Akademvydav, 352 s. [in Ukrainian].

Osvitnii potentsial TRVZ (teoriia rozviazannia vynakhidnytskykh zadach) [Educational potential of TRVZ (theory of solving inventive problems)]. (2014). Chastyna 1 / S. A. Bolsun. Kh.: Vyd. hrupa «OsnovaC, 128 s.; Vyp. 5 (137). [in Ukrainian].

Podymova, L., Sergeyeva, V., Sorokovykh, G. (2011). Interaktivnyye metody v obuchenii $i$ vospitanii $v$ sisteme obshchego. srednego $i$ vysshego professionalnogo obrazovaniya. [Interactive methods in teaching and education in the system of general, secondary and higher professional education.] Uchebno-metodicheskoye posobiye. Moskva. URL: https://lektsii.org/8-36203.htm [Data zvernennia 10.09.2021]. [in Russian].

Sysoieva, S. (2014). Tvorchyi rozvytok fakhivtsiv v umovakh mahistratury [Creative development of specialists in the conditions of a magistracy]: Monohrafiia. Kyiv: TOV. "Vyrobnyche pidpryiemstvo EDELVEIS", 400 s. [in Ukrainian].

Skhodynkamy tvorchosti. Metodyka TRVZ v pochatkovii shkoli [Steps of creativity. Methods of TRVZ in primary school] (2007). Avtory-uporiadnyky: O. V. Lesina, V. P. Teliachuk. Kh.: Vyd. hrupa "Osnova": "Triada+", 112 s. [in Ukrainian].

\section{TECHNOLOGIES FOR THE DEVELOPMENT OF FUTURE PRESCHOOL EDUCATION TEACHERS' CREATIVE THINKING}

\author{
Liudmyla Kozak \\ Doctor of Sciences (in Pedagogy), Associate Proffesor, \\ Professor at the Department of Preschool Education, \\ Borys Hrinchenko Kyiv University, \\ Kyiv, Ukraine \\ ORCID: 0000-0002-4528-1905 \\ e-mail:l.kozak@kubg.edu.ua
}




\section{Інноватика у вихованні. Випуск 14. 2021.}

Abstract. The article analyses the researches of domestic and foreign scientists who consider technologies aimed at developing of students' creative thinking; the concept of creativity, mechanisms of creative thinking, its specific features, stages of creative process are considered; the technology of problembased learning is characterized, in particular: purpose, main features, methods of creating problem-solving situations, stages of solving educational problems, levels of organization and ways of implementing problem-based learning in higher education institutions, advantages and limitations in technology application; it is established that the most important feature of the substantive aspect of problem-based learning is the reflection of objective contradictions that naturally arise in the process of scientific knowledge, learning or any other activity, which are the source of movement and development in any field; it is noted that the technology of problem-based learning is implemented in practice as an independent, autonomous or as an organic part of other learning technologies (game technologies, cooperative technologies, project-based learning, etc.); the semantic characteristic of the Theory of Inventive Tasks Solving (TITS) as a technology of creative personality development is given; a digression into the history of the technology creation is made; the main provisions of TITS concerning pedagogy are given; the essence, purpose, main features, main principles of technology, algorithm for solving inventive tasks are revealed; some techniques and methods developed within the framework of TITS, as well as such well-known methods as brainstorming, synectics, morphological analysis, the method of focal objects are considered; positives and difficulties in using the technology are identified. The conclusion on the possibility of using the technology in working with preschool programme students in the educational process of higher education establishment is made.

Keywords: algorithm; method; reception; problem-based learning; creativity; creative thinking; Theory of Inventive Tasks Solving; technology.

Стаття надійшла до редакиії 01.10.2021p. 